\title{
COLUMN PERFORMANCE IN LEAD(II) REMOVAL FROM AQUEOUS SOLUTIONS BY FIXED-BED COLUMN OF MANGO WOOD SAWDUST (MANGIFERA INDICA)
}

\author{
Miranti Puspitasari \\ Jurusan Kimia, Fakultas Matematika dan Ilmu Pengetahuan Alam, \\ Universitas Jember \\ e-mail: puspitasari.miranti.91@gmail.com
}

Received 6 Maret 2018

Accepted 2 Mei 2018

\begin{abstract}
The contamination of water resources due to the exceed $\mathrm{Pb}$ content is becoming an environmental serious problem. Adsorption method in dynamic system using fixed-bed column can be used to reduce the level of $\mathrm{Pb}$ in an attempt to suppress the toxic effects caused by $\mathrm{Pb}$. This study aims to optimize the parameters of $\mathrm{Pb}$ adsorption on samples by mango wood sawdust in a dynamic system. Mango wood sawdust was activated by $\mathrm{HNO}_{3}$ and ethanol then packed in a column. Optimization of adsorption parameters including adsorbent heating temperature, adsorbent mass, $\mathrm{pH}$ of the influent solution, and the influent flow rate. The experiment result showed that the optimum conditions of mango wood sawdust to reducing $\mathrm{Pb}$ in samples are adsorbent was heated at temperature $145^{\circ} \mathrm{C}$, using 3 $\mathrm{g}$ adsorbent packed in a column, and the influent solution at $\mathrm{pH} 7$ was passed at a flow rate $1 \mathrm{~mL} / \mathrm{min}$. Adsorption capacity of mango wood sawdust in reducing $\mathrm{Pb}$ in samples at optimum condition is equal to $14,8 \mathrm{mg} / \mathrm{g}$ of adsorbent and the type of adsorption that occurs between the adsorbent with adsorbate is chemical adsorption.
\end{abstract}

Keywords: Adsorption, dynamic system, fixed-bed column, mango wood sawdust, lead metal

\section{Introduction}

Pollution of water resources due to waste disposal containing heavy metals into water bodies has become a major environmental problem as some metals are known to have toxic effects to humans and to the environment ecology (Meneghetti et al., 2010). One of the metals known to have toxic effects is lead. The effect of lead toxicity arises when it enters into an organism or an environmental component beyond the tolerance limit. Government Regulation of the Republic of Indonesia No. 82 Years 2001 on Water Quality Management and Water Pollution Control states that the tolerance limit of lead content in water bodies is $0,03 \mathrm{mg} / \mathrm{L}$ for group I, II, III and $1 \mathrm{mg} / \mathrm{L}$ water for group IV water.

Adsorption in dynamic systems can be one preferred methods for dealing with water pollution by lead because it is more efficient and effective, and can be widely used in industrial wastewater treatment systems. The adsorption process can use adsorbents from biomaterials as an alternative to zeolite as well as activated carbon, thus reducing costs. The adsorption process using biosorbent was known as biosorption (Ngah \& Hanafiah, 2008).

One of the potentially adsorbent biomaterials is the wood sawdust from the plant. Wood is composed of cellulose, hemicellulose, lignin, polysaccharides, extractive substances, and inorganic components. Lignocellulose and hemicellulose that chemically bound to wood contribute to metal ion adsorption process. One plant that has high lignocellulose content is a mango tree. Mango tree wood composed of $36 \%$ cellulose; 49,5\% lignin; and the remainder are other wood constituent components (Arthisree \& Sirisha, 2012). The high content of lignocelluloses in mango wood becomes the main reason for metal ions adsorbents in the adsorption process by dynamic system. 


\section{Material and Method}

Materials and equipment

The materials used in this research were mango wood sawdust, distilled water, $\mathrm{Pb}\left(\mathrm{NO}_{3}\right)_{2} .4 \mathrm{H}_{2} \mathrm{O} \quad(\mathrm{Mr}=321,68 \mathrm{~g} / \mathrm{mol}$, Merck), lead standard for Atomic Absorption Spectroscopy (1000 mg/L in $\mathrm{HNO}_{3}$, TraceCERT, Sigma-Aldrich), $\mathrm{CH}_{3} \mathrm{COOH} 100 \%$ (Merck), $\mathrm{CH}_{3} \mathrm{COONa}$ anhydrous $\geq 99,0 \%$ (ReagentPlus, SigmaAldrich), $\mathrm{K}_{2} \mathrm{HPO}_{4} \geq 98 \%$ (ACS reagent, Sigma-Aldrich), $\mathrm{KH}_{2} \mathrm{PO}_{4} \geq 99,0 \%$ (ACS reagent, Sigma-Aldrich), $\mathrm{HNO}_{3}$ 69-70\% (ultrapure grade, Merck), ethanol absolute (ACS reagent, Merck), and glasswool for laboratory use (Sigma-Aldrich).

The equipment and laboratory instrument used in this research were fixed-bed column set, wood sawdust machine M-400, laboratory mill Wagtech Projects AG62-700, laboratory sieve shaker Aelab RP200-N, pH meter Jenway 3505, oven Memmert UF110, atomic absorption spectrophotometer Buck Scientific 205, FT-IR spectrophotometer Perkin Elmer 1600 series, analytical balances Mettler Toledo MS-TS, and laboratory glassware.

\section{Procedure \\ Lead solutions preparation}

The lead stock solution $(1,000 \mathrm{mg} / \mathrm{L})$ was prepared by dissolving the appropriate amount of $\mathrm{Pb}\left(\mathrm{NO}_{3}\right)_{2} .4 \mathrm{H}_{2} \mathrm{O}$ in distilled water. Necessary dilutions were done to obtain $30 \mathrm{mg} / \mathrm{L}$ of lead solution. Standard concentrations of $1 ; 2 ; 3 ; 4$; and $5 \mathrm{mg} / \mathrm{L}$ of $\mathrm{Pb}$ (II) solutions were also prepared for calibration purposes.

\section{Adsorbent preparation}

Fresh and mature mango woods were collected during April to May, 2013 from a mango plantation in Sidoarjo, Indonesia. The mango woods then grounded by a wood sawdust machine and washed thoroughly using distilled water. The mango wood sawdust then dried in an oven at $60^{\circ} \mathrm{C}$ for 24 hours, and sieved using a 60 mesh sieve, then soaked with $0,1 \mathrm{M} \mathrm{HNO}_{3}$ for 2 days. The mango wood sawdust was neutralized using distilled water, then immersed in $70 \%$ ethanol for 5 hours, and aerated to dry. The resulting adsorbent was kept in a glass bottle for further experiment.

\section{Column adsorption studies}

All adsorption experiments were conducted in triplicates and the results are reported as average. The fixed bed column studies were carried out using a glass column of $1 \mathrm{~cm}$ internal diameter and 30 $\mathrm{cm}$ height, supplied by Pyrex. The tank containing the lead solutions was placed at a higher elevation and the flow rate of the lead solutions flowing into the column was regulated by the pump. Adsorbent was heated with a certain temperature variation, and weighed with a certain mass variation, then packed in the glass column that previously filled with glasswool as shown in Figure 1. The $\mathrm{pH}$ of influent was conditioned on certain $\mathrm{pH}$ variations, and flowed into columns with predetermined flow rate variations.

The effect of adsorbent heating temperature was investigated in various temperature. Adsorbents were heated with temperature variations of $100-145^{\circ} \mathrm{C}$. The effect of adsorbent mass was studied by varying the amounts of adsorbent from 1 to $3 \mathrm{~g}$. The effect of influent $\mathrm{pH}$ was investigated over a $\mathrm{pH}$ range 4-8 using phosphate buffer and acetate buffer. The effect of influent flow rate was investigated with variations from 1 to 8 $\mathrm{mL} / \mathrm{min}$. The amount of $\mathrm{Pb}$ (II) ions in the solutions before and after adsorption process was analyzed by atomic absorption spectrophotometer at a wavelength of 217 $\mathrm{nm}$.

The adsorption capacity of mango tree powder to lead ions was determined on the optimum adsorption conditions. The Thomas model was used to determine adsorption capacity of the column. The expression by Thomas for an adsorption column is given in equation 1 . The linearized form of the Thomas model is as equation (2) Where $K_{T h}$ is the Thomas rate constant $(\mathrm{L} / \mathrm{min} . \mathrm{mg}) ; q_{o}$ is the adsorption capacity $(\mathrm{mg} / \mathrm{g}) ; \mathrm{M}$ is the total mass of the adsorbent $(\mathrm{g}) ; V_{\text {eff }}$ is the effluent volume (L); $C_{o}$ is the influent concentrations $(\mathrm{mg} / \mathrm{L}) ; C_{e}$ is the effluent concentrations $(\mathrm{mg} / \mathrm{L})$; and $Q$ is the influent flow rate (L/min).

$$
\begin{gathered}
\frac{C_{e}}{C_{o}}=\frac{1}{1+e^{\left[\frac{K_{T h}}{Q}\left(q_{o} M-C_{o} V_{e f f}\right)\right]}} \\
\ln \left(\frac{C_{o}}{C_{e}}-1\right)=\frac{K_{T h} q_{o} M}{Q}-\frac{K_{T h} C_{o}}{Q} V_{e f f}
\end{gathered}
$$


Adsorbents before and after use in the adsorption process were characterized using a FT-IR spectrophotometer at wavenumbers $4000-400 \mathrm{~cm}^{-1}$, then the two spectra were compared to confirm whether the adsorption process occurred physically (physisorption) or chemically (chemisorption).

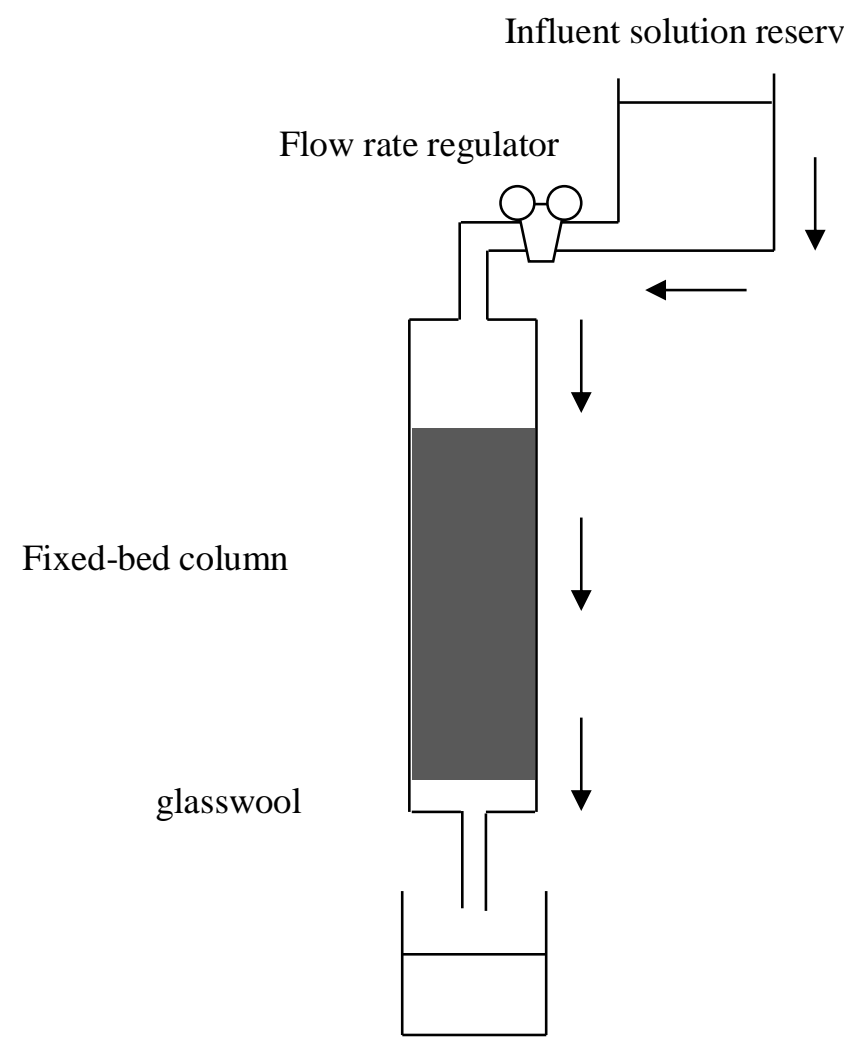

Effluent solution reservoir

Figure 1. Schematic diagram of fixed-bed column in dynamic system

\section{Result and Discussion}

Effect of adsorbent heating temperature

The $\mathrm{Pb}(\mathrm{II})$ concentration in effluent solution decreases from a temperature range of $100^{\circ} \mathrm{C}$ to $145^{\circ} \mathrm{C}$ (Figure 2). The increase of the adsorbent heating temperature causes more water molecules released from the adsorbent pores due to the evaporation process, so the adsorbent porosity increases because the pores that were originally covered by water molecules will be opened after the water molecules evaporate. The increase of adsorbent porosity causes an increase in adsorbate molecules that can be adsorbed. The $\mathrm{Pb}(\mathrm{II})$ concentration in effluent solution increases again at $160^{\circ} \mathrm{C}$. The adsorbent heating exceeds the optimum temperature causing some lignocellulosic bonds to break up due to dehydration reaction so that the adsorbent active side was damaged and reduces the amount of adsorbate that can be adsorbed.

Lignocellulose degradation process begin to occur at temperatures of 100$250^{\circ} \mathrm{C}$ because cellulose was degraded to levoglucose whereas lignin will be degraded into aromatic hydrocarbon components, as indicated by a decrease in the cellulose polymerization degree. The starting temperature of lignocellulosic degradation depends on the thermal stability characteristics of various components in the lignocellulose constituent (Rowell \& Mc. Sweeny, 2008). 


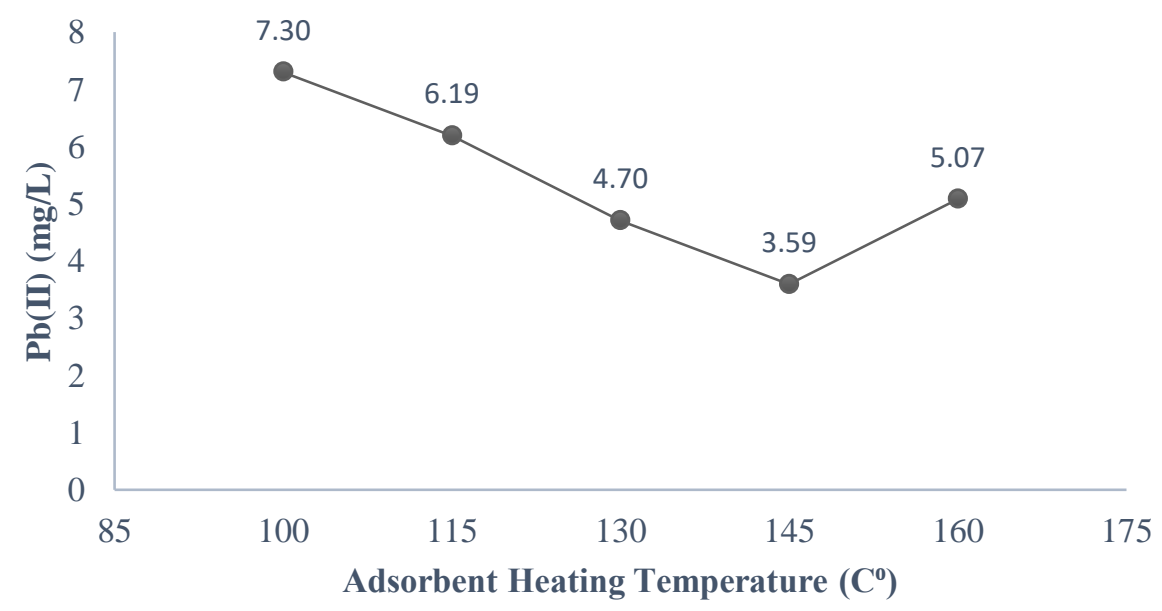

Figure 2. The relationship between the absorbent heating temperature and the $\mathrm{Pb}(\mathrm{II})$ concentration in effluent solution

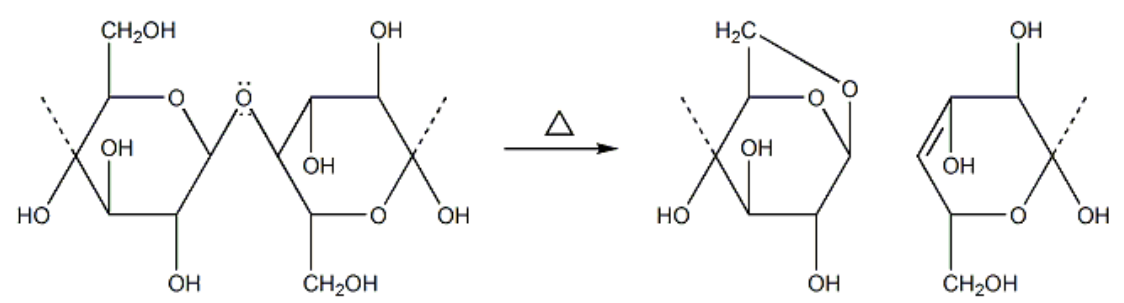

Figure 3. Lignocellulose degradation formed levoglucose (Rowell \& Mc. Sweeny, 2008)

\section{Effect of adsorbent dose}

Figure 4 shows that an increase in adsorbent mass causes a decrease in the $\mathrm{Pb}$ (II) concentration in effluent solution. The increase in the adsorbent mass leads to an increase in the availability of the active side and provides more opportunities for the $\mathrm{Pb}$ (II) ions to interact with the adsorbent because there will be more available adsorption sites that can bind with the adsorbate (Mahajan \& Sud, 2013).

\section{Effect of influent $p H$}

$\mathrm{pH}$ is an important controlling parameter in the adsorption process due to its influence on the surface properties of the adsorbent and the ionic form of the metal ion in solution. Solution $\mathrm{pH}$ can affect the chemical speciation of lead ions and surface binding sites of the adsorbent. Figure 4 shows that the $\mathrm{Pb}$ (II) concentration in effluent solution at $\mathrm{pH} 4$ has the highest value. Influent solution at $\mathrm{pH} 4$ has a relatively high content of $\mathrm{H}^{+}$ ions compared to the influent solution at $\mathrm{pH} 5$ to 8 . $\mathrm{H}^{+}$ions competes with $\mathrm{Pb}^{2+}$ ions to bind to free electrons of $\mathrm{O}$ atoms at the -OH group (Ngah \& Hanafiah, 2008). The -OH group tends to be protonated because the $\mathrm{O}$ atoms of the $-\mathrm{OH}$ group (hard base) are more likely to bind to the $\mathrm{H}^{+}$ions (hard acid) than the $\mathrm{Pb}^{2+}$ ions (borderline acid), in accordance to the principle of HSAB (Hard Soft Acids and Bases). This causes the $-\mathrm{OH}$ groups on lignocellulose are more difficult to bind to $\mathrm{Pb}^{2+}$ ions at low $\mathrm{pH}$ (Alfarra et al., 2004).

With increasing $\mathrm{pH}$ from $\mathrm{pH} 5$ to 7 causes decreasing the $\mathrm{H}^{+}$ion content in the influent solution, thereby reducing competition between $\mathrm{H}^{+}$ions and $\mathrm{Pb}^{2+}$ ions to occupy the active site on lignocellulose. This phenomenon causes an increase of $\mathrm{Pb}^{2+}$ ion adsorption by lignocellulose active site. An increase in influent $\mathrm{pH}$ would also cause ligands groups contained in lignocellulose, such as - $\mathrm{COOH}$ or $-\mathrm{COH}$ undergo deprotonation resulting the negatively charged group $-\mathrm{COO}^{-}$and $-\mathrm{CO}^{-}$ which attract $\mathrm{Pb}^{2+}$ ions (Ngah \& Hanafiah, 2008). 


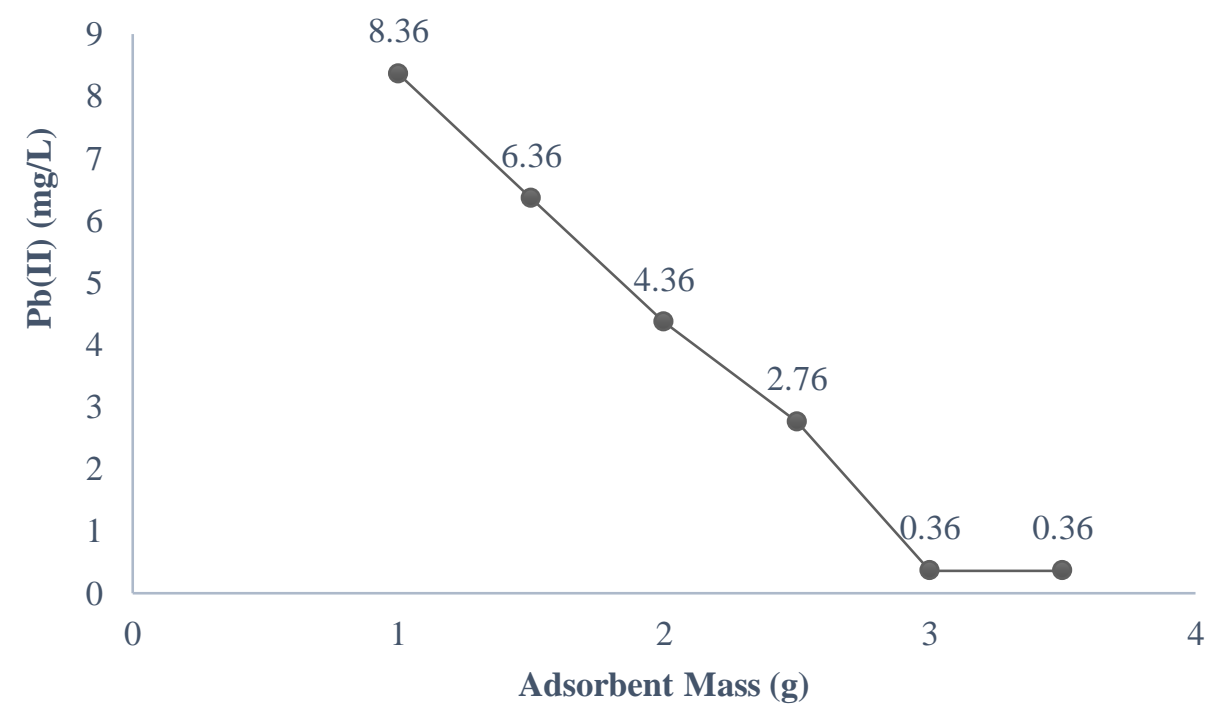

Figure 4. The relationship between the absorbent dose and the $\mathrm{Pb}$ (II) concentration in effluent solution

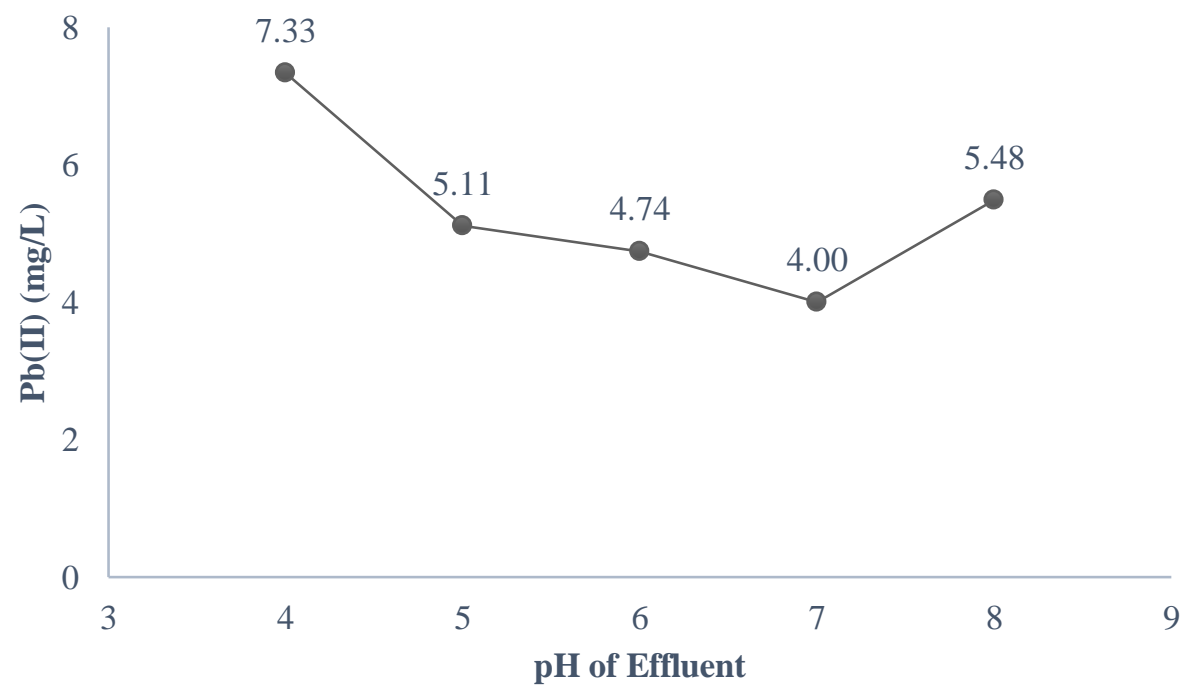

Figure 5. The relationship between the influent $\mathrm{pH}$ and the $\mathrm{Pb}(\mathrm{II})$ concentration in effluent solution

Effect of influent flow rate

The $\mathrm{Pb}$ (II) concentration in effluent solution increased from a variation in flow rate of $1 \mathrm{~mL} / \mathrm{min}$ to $8 \mathrm{~mL} / \mathrm{min}$ (Figure 6). The slower the flow rate then the time that can be used by adsorbate to interact with adsorbent also increase and vice versa. The condition at the highest flow rate $(8$ $\mathrm{mL} / \mathrm{min}$ ) causes the influent solution to flow faster so the distribution to the adsorbent pores is not maximum. The influent fluid that flows at a particular $t$ will be pushed quickly by the influent fluid that flows on the next $t$ before some adsorbate could interacts with the adsorbent. So, the adsorption process is not running maximally, and the adsorbate out from the column before the adsorption process occurred (Sari \& Erdawati, 2013). The optimum flow rate condition is at a flow rate of $1 \mathrm{~mL} / \mathrm{min}$ because it has the least $\mathrm{Pb}$ (II) concentration in effluent solution compared to other flow rate variations.

\section{Adsorption kinetic model}

The breakthrough curve showed that the break point $\left(C_{e}=5 \% C_{0}\right)$ was achieved at $200 \mathrm{~mL}$ effluent volume and exhaustion point $\left(C_{e}=95 \% C_{0}\right)$ was achieved at 800 mL effluent volume. Adsorbents packed in columns are saturated after reaching a 900 
mLeffluent volume (Figure 7). The greater effluent volume at break point indicates that more influent volumes that can be treated by adsorbents in the column during the concentration of $\mathrm{Pb}(\mathrm{II})$ in the effluent still not exceeding $5 \%$ of the influent concentration because if the $C_{e} / C_{0}$ ratio has exceeded $5 \%$ then the adsorption process using the adsorbent in the column is not effective. The data obtained from this research process provides an overview of influent volume that can be processed until the adsorbent was saturated and this is very useful if the system applied in large-scale fixed-bed column design for processing solution containing $\mathrm{Pb}$ (II) with known concentration. The Thomas model approach was used in studying fixed-bed column that used in this research. The advantages of Thomas model over the other approach model for studying the adsorption process in fixed-bed column because Thomas model can be used to determine the adsorption capacity of the column. The Thomas rate constant $\left(K_{T h}\right)$ in this study was $2,95 \times 10^{-4} \mathrm{~L} / \mathrm{min} . \mathrm{mg}$ indicating that $1 \mathrm{mg}$ of adsorbent can absorb $\mathrm{Pb}$ (II) $30 \mathrm{ppm}$ flowing at 2,95 $\times 10^{-}$ $4 \mathrm{~L}$ per minute, while the column adsorption capacity $\left(q_{o}\right)$ of $14,8 \mathrm{mg} / \mathrm{g}$ of adsorbent indicating that 1 gram of adsorbent can absorb 14,8 mg Pb(II).
The adsorption capacity of the adsorbent is one of the key factors in assessing of its potential for commercial applications. The adsorption capacity obtained in this work was higher than the ones obtained by Nwabanne and Igbokwe (2012), which studied the adsorption of $\mathrm{Pb}$ (II) $100 \mathrm{mg} / \mathrm{L}$ at a flow rate of $5 \mathrm{~mL} / \mathrm{min}$ using coconut fiber packed in fixed-bed column that obtained adsorption capacity of $3,93 \mathrm{mg} / \mathrm{g}$. The research conducted by Murathan et al. (2008) in studying adsorption of $\mathrm{Zn}$ (II) $97,8 \mathrm{mg} / \mathrm{L}$ at a flowrate of $0,075 \mathrm{~L} / \mathrm{sec}$ using the seed of oak tree packed in fixed-bed column have lower adsorption capacity value too, that is $3,34 \mathrm{mg} / \mathrm{g}$.

\section{Adsorption characterization}

The FT-IR spectra of adsorbent powder displays a number of absorption peak (Figure 8) which indicates the presence of different types of functional groups in the adsorbent. The broad and strong band at $3365 \mathrm{~cm}^{-1}$ indicates the presence of $-\mathrm{OH}$ groups, which is consistent with the peak at $1055 \mathrm{~cm}^{-1}$ assigned to alcoholic stretching vibration. The peak at $1648 \mathrm{~cm}^{-}$ ${ }^{1}$ corresponds to the $\mathrm{C}=\mathrm{O}$ stretching. The peak located at $1164 \mathrm{~cm}^{-1}$ is a characteristic of $\mathrm{C}-\mathrm{O}-\mathrm{C}$ asymmetrical stretching.

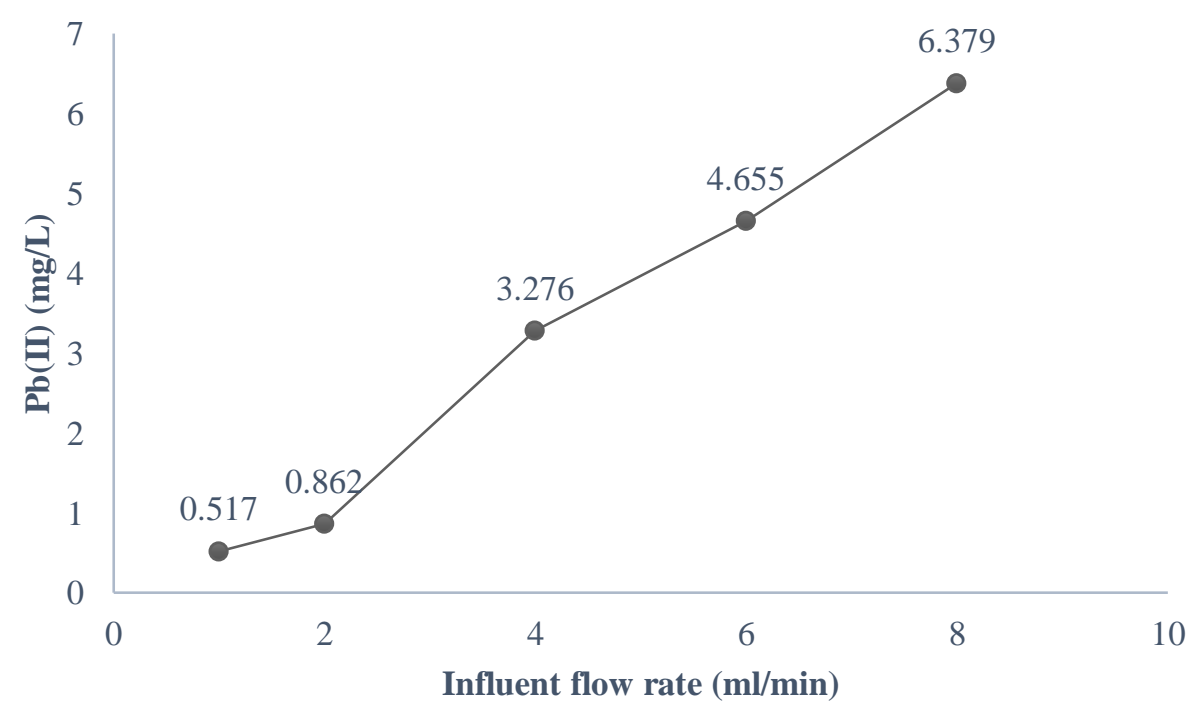

Figure 6. The relationship between the influent flow rate and the $\mathrm{Pb}$ (II) concentration in effluent solution 


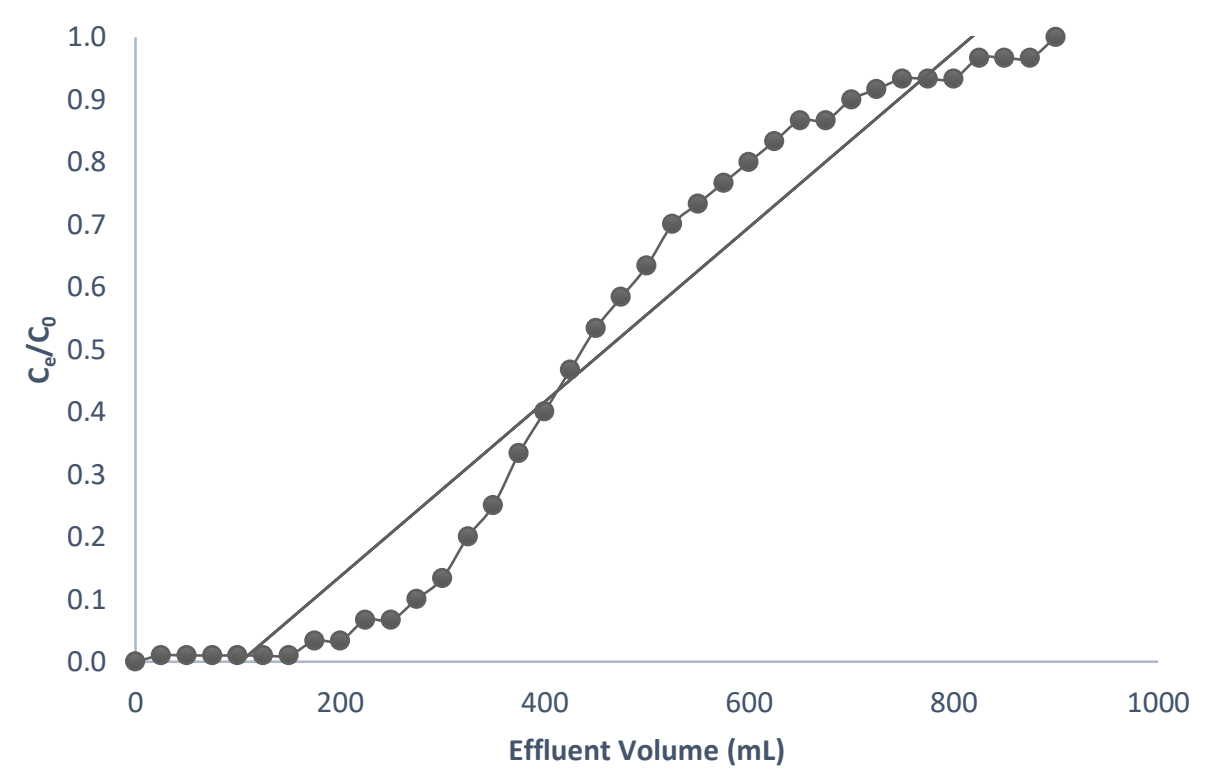

Figure 6. The breakthrough curve of $\mathrm{Pb}(\mathrm{II})$ adsorption by mango wood sawdust (Mangifera indica)

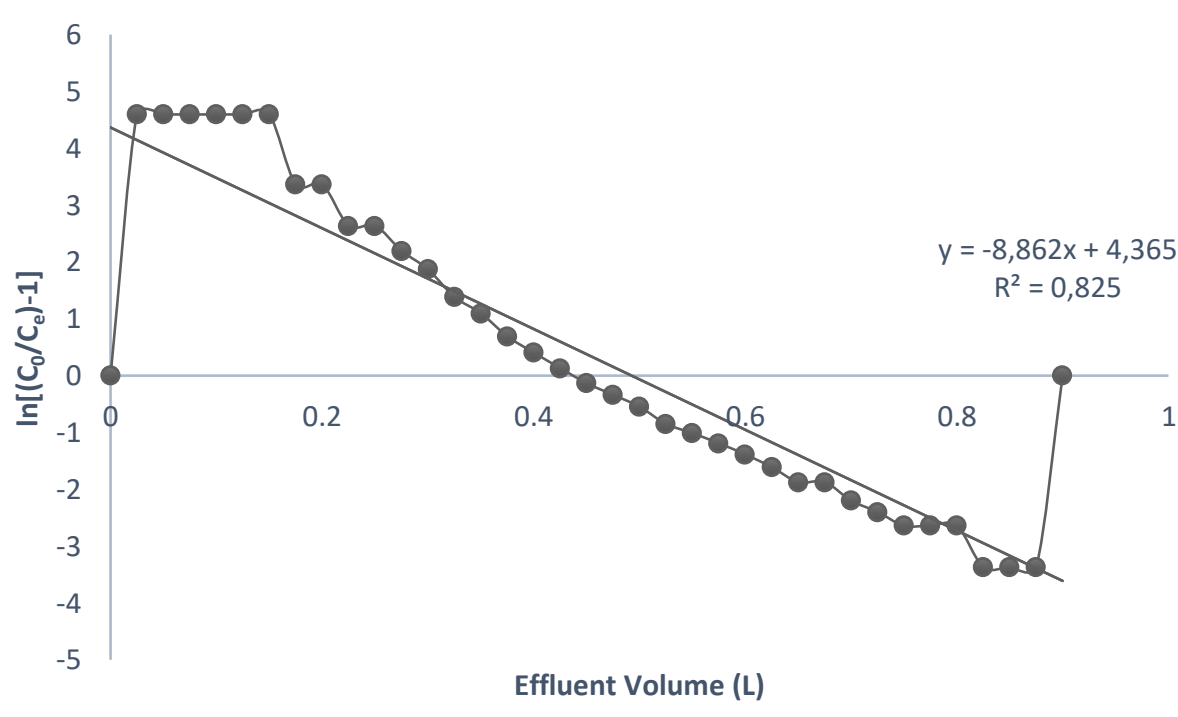

Figure 7. The relationship between the effluent volume and $\ln \left[\left(\mathrm{C}_{\mathrm{o}} / \mathrm{C}_{\mathrm{e}}\right)-1\right]$

The FT-IR spectra for lead loaded adsorbent showed wavenumber and intensity of some peaks were disappeared after lead intake, suggesting the participation of adsorption groups in the binding of lead by adsorbent (Figure 8). The loss of $\mathrm{O}-\mathrm{H}$ and $\mathrm{C}=\mathrm{O}$ group peak indicates that both of these functional groups participate in the binding of $\mathrm{Pb}(\mathrm{II})$. The appearance of a new peak after lead adsorption by adsorbent at the $614 \mathrm{~cm}^{-1}$ is the peak of the $\mathrm{Pb}-\mathrm{O}$ group because the $\mathrm{Pb}$ O spectra appears in the $400-700 \mathrm{~cm}^{-1}$ (Ricks \& Ogden, 2003; Niasari et al., 2009; Cattley et al., 2010; and Gautam et al., 2009). Thus, the mechanism of lead binding on adsorbent could also occur by surface complexation to perform chemical adsorption (chemisorption). 


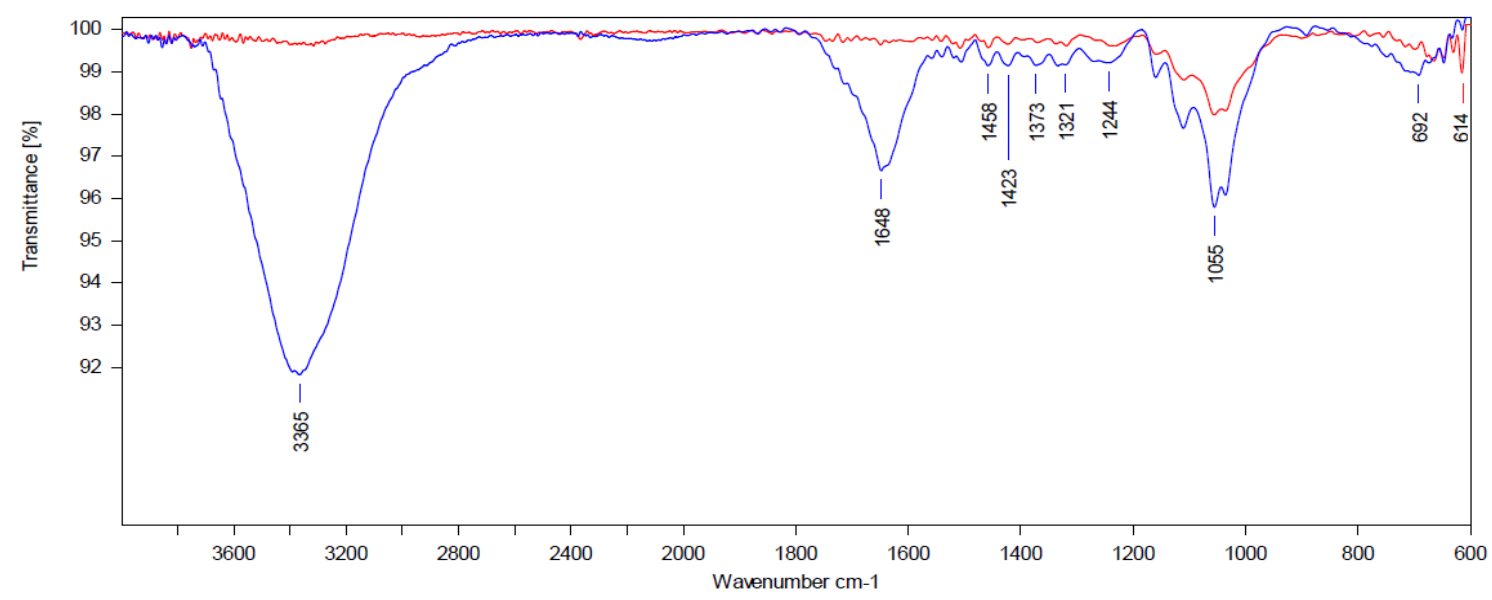

Figure 8. FT-IR spectra of adsorbent before (blue line) and after lead adsorption (red line)

Table 1. Comparison of wavenumbers before and after lead adsorption

\begin{tabular}{lrrrl}
\hline & \multicolumn{3}{c}{ Wavenumber $\left(\mathrm{cm}^{-1}\right)$} & \\
\cline { 2 - 4 } No. & $\begin{array}{c}\text { Before } \\
\text { Adsorption }\end{array}$ & $\begin{array}{c}\text { After } \\
\text { Adsorption }\end{array}$ & Literature* & \\
\hline 1. & 1055 & 1056 & 1046 & C-OH \\
2. & 1164 & 1165 & 1152 & C-O-O -C asymmetrical stretching \\
3. & 1648 & - & 1724 & C=O stretching \\
4. & 3365 & - & 3327 & O-H stretching \\
\hline
\end{tabular}

*Fan et al., 2012

\section{Conclusion}

The results showed that mango wood sawdust packed in fixed-bed column could be used as promising adsorbent for treating lead solution. This new biosorbent is able to remove the lead ions from aqueous solutions and the adsorption process in dynamic system is strongly dependent on the adsorbent heating temperature, adsorbent mass, influent $\mathrm{pH}$, and influent flow rate. Adsorption capacity mango wood sawdust packed in fixed-bed column for treating lead solutions could determine by Thomas approach model. The experiment result showed that the optimum conditions of mango wood sawdust to reducing $\mathrm{Pb}$ in samples are

\section{Reference}

Alfarra, A., Frackowiak, E., and Beguin, F., 2004, The HSAB Concept as A Means to Interpret The Adsoprtion of Metal Ions onto Activated Carbons, App. Surf. Sci., 228 (1-4): 84-92.

Arthisree, S.R. \& Sirisha, D., 2012, Adsorption of Aqueous Solution of $\mathrm{NO}_{2}$ by Mango Bark Powder, Univ. $J$. Environ. Res. Tech., 2 (1): 112-114. adsorbent was heated at temperature $145^{\circ} \mathrm{C}$, using $3 \mathrm{~g}$ adsorbent packed in a column, and the influent solution at $\mathrm{pH} 7$ was passed at a flow rate $1 \mathrm{~mL} / \mathrm{min}$. Adsorption capacity of mango wood sawdust in reducing $\mathrm{Pb}$ in samples at optimum condition is equal to $14,8 \mathrm{mg} / \mathrm{g}$ of adsorbent The binding of lead ions by adsorbent also took place on various functional groups such as hydroxyl and carboxyl as demonstrated by FT-IR spectra. Surface complexation to perform chemisorption process have been identified as the main mechanisms involved in the binding of lead ions on adsorbent.

Cattley, Stavrinadis, Beal, Moghal, Cook, Grant, Smith, Assender, and Watt, 2010, Colloidal Synthesis of Lead Oxide Nanocrystals for Photovoltaics, Chem. Commun., 46: 2802-2804.

Fan, M., Dai, D., and Huang, B., 2012, Fourier Transform Infrared Spectroscopy for Natural Fibres, Materials. Anal., 45-68. 
Gautam, C. R., Kumar, D., and Parkash, O. M., 2009, IR Study of Pb-Sr Titanate Borosilicate Glasses, Bull. Mater. Sci., 33 (2): 145-148.

Mahajan, G. \& Sud, D., 2013, Bioremediation of $\mathrm{Cr}$ (VI) Metal Ion from Aqueous Solutions Using Modified Lignocellulosic Agricultural Waste Biomass, Int. J. Adv. Tech. Eng. Res., 3 (2): 35-43.

Meneghetti, E., Baroni, P., and Vieira, R. S., 2010, Dynamic Adsorption of Chromium Ions onto Natural and Cross-linked Chitosan Membranes for Wastewater Treatment, Materials Res, 13 (1): 89-94.

Murathan, A. S., Murathan, A., and Yucekutlu, A. Y., 2008, Adsorption of Zinc Ions in Fixed Beds, J. Int. Environ. App. Sci., 3 (5): 422-425.

Ngah, W. S. W. \& Hanafiah, M. A. K. M., 2008, Biosorption of Copper Ions from Dilute Aqueous Solutions on Base Treated Rubber (Hevea brasiliensis) Leaves Powder: Kinetics, Isotherm, and Biosorption Mechanisms, J. Environ. Sci., 20: 1168-1176.
Niasari, M. S., Mohandes, F., and Davar, F., 2009, Preparation of $\mathrm{PbO}$ Nanocrystals via Decomposition of Lead Oxalate, Polyhedron, 28 (11): 2263-2267.

Ricks, M. J. \& Ogden, J. S., 2003, Matrix Isolation Studies of Group IV Oxides: IV. Infrared Spectra and Structures of $\mathrm{PbO}, \mathrm{Pb}_{2} \mathrm{O}_{2}$, and $\mathrm{Pb}_{4} \mathrm{O}_{4}$. J. Chem. Phys., 56: 1658.

Rowell, R. M. \& Mc. Sweeny, J. D., 2008, Heat Treatments of Wood Fibers for Self-Bonding and Stabilized Fiberboards, J. Mol. Crys. Liq. Crys., 483 (1): 307-325.

Sari, R. P. \& Erdawati, 2013, Adsorpsi Congo Red dengan Nanokomposit Chitosan-Montmorillonite secara Kolom, Seminar Nasional Material, 65-69.

The Republic of Indonesia, 2001, Government Regulation of the Republic of Indonesia No. 82 Years 2001 on Water Quality Management and Water Pollution Control, Jakarta. 